\title{
Short-term variations in the fluxes and composition of seston in near-bottom traps in the southern North Sea
}

Received: 15 January 2001 / Revised: 13 November 2001 / Accepted: 15 November 2001 / Published online: 22 January 2002 C) Springer-Verlag and AWI 2002

\begin{abstract}
In this study we attempted to measure the potential food availability for macrobenthic interface feeders using a new device (sediment recorder) which traps bed load particles at a height of $10 \mathrm{~cm}$ above the sea floor. The recorder is positioned flat on the seabed and alternately exposes a shallow collector mounted in a smooth surface mimicking the sediment surface. The samples were analyzed for their content of chlorophyll $a$ (Chl) and dry weight (DM). We compared the sediment recorder data with the results obtained with a sediment trap suspended $3.2 \mathrm{~m}$ above the sea floor. Measurements were carried out in spring and fall at two stations in the southern North Sea with different sediment type, maximum current velocities and biomass (sand, station B vs silty sand, station F). The recorder deployments in November yielded higher Chl fluxes and a higher quality of particles (Chl:DM ratio) than the trap at both stations. Unlike the trap samples, in which Chl and DM were always positively and strongly correlated, maximum $\mathrm{Chl}$ and DM fluxes in the recorder samples were out of phase, particularly at station B, pointing to a highly variable quality during the tidal cycle. Unexpectedly, Chl fluxes and Chl:DM ratios in the recorder samples at station $\mathrm{B}$ were higher than at station $\mathrm{F}$ in both seasons, although the benthic biomass at the latter station was five times higher. The highest $\mathrm{Chl}$ fluxes and particle quality (Chl:DM) at station B were measured during slack tides when interface feeding would be least hampered by drag forces. Station B is nevertheless characterized by a low macrobenthic biomass and a scarcity of interface feeders, specifically of suspension-feeding bivalves. Possible reasons for this apparent discrepancy are discussed.
\end{abstract}

Communicated by H.-D. Franke

G.C.A. Duineveld $(\bowtie) \cdot A . R$. Boon

Netherlands Institute for Sea Research, PO Box 59,

1790 AB Den Burg, The Netherlands

e-mail: duin@nioz.nl

Tel.: +31-222-369300, Fax: +31-222-319674
Keywords Tidal cycle $\cdot$ Near-bottom particle fluxes . Phytopigments · North Sea

\section{Introduction}

While the primary production and pelagic food webs determine the export of organic matter to the sea floor, the actual quantity and quality of the particulate matter near the bottom in shelf seas, such as the North Sea, is strongly influenced by tidal current and waves (Mills 1975; Fegley et al. 1992; Jago and Jones 1998; van Raaphorst et al. 1998). The importance of these processes for the ecology of benthic organisms has been emphasized by Snelgrove and Butman (1994) and Eckman (1996). Laboratory and field studies have demonstrated strong interactions between particulate organic matter sedimentation and resuspension, on the one hand, and the feeding activity and physiology of benthic organisms, on the other (Miller et al. 1992; Abelson et al. 1993; Bayne et al. 1993; Davoult and Gounin 1995; Loo et al. 1996). Because of these interactions, the structure of benthic communities is often found to be closely correlated to the hydrodynamic regime near the seabed (Rosenberg 1995).

Creutzberg et al. (1984) and Creutzberg (1986) have already inferred such relationships in their study on the zonation of macrobenthos near a tidally induced front in the southern North Sea. Subsequent field measurements on the interaction between tidal currents and the benthic food supply in the southern North Sea showed that in sandy sediments fresh organic matter was alternately deposited during slack tides, and this might explain high growth rates of macrobenthos in the otherwise organic poor substrate (Jenness and Duineveld 1985). Later studies (Jago et al. 1993; Boon and Duineveld 1996; van Duyl et al. 1997; van Raaphorst et al. 1998) showed temporal (tidal) fluctuations in quantity and quality of nearbottom particulate matter to be a common phenomenon in the southern North Sea, and the magnitude of the fluctuations to vary geographically. In most of these studies on near-bottom particulate fluxes, instruments (sediment 
trap, transmissometer) were used which had been moored several meters above the seabed. However, as most interface-feeding macrobenthos in the southern North Sea collect food particles within a layer of several centimeters above the sediment surface, it is more appropriate from the perspective of benthic ecology to study variations in the particle quality and quantity in this particular layer.

In this study we measured particle fluxes and quality at $10 \mathrm{~cm}$ above the sea floor. For this purpose we built a new trapping device (sediment recorder), which was designed to mimic the sediment surface and as such to trap bed load particles. In order to illustrate the different outcomes obtained with our new device, we compare these results with those acquired with a traditional sediment trap that we simultaneously deployed at a height of several meters above bottom. This comparison was conducted at two locations, i.e., a sand station with relatively high maximum currents ( $\operatorname{stn} \mathrm{B}$ ), and a more quiescent, silty sand station (stn F). As a measure for high quality benthic food particles we used chlorophyll $a(\mathrm{Chl})$ and hence focused our analysis on the Chl fluxes and on the Chl:DM (dry matter) ratio being a quality index. We did not take organic carbon as a measure of food, since the sediment at stn $\mathrm{F}$ is known to contain a high load of refractory carbon. More generally, chlorophyll $a$ is a better food marker than organic $\mathrm{C}$ because of its short lifetime (Sun et al. 1994; Wakeham et al. 1997), and because several studies have shown that macrobenthos specifically select particles containing phytopigments (chlorophyll) from the suspended matter (Christensen and Kanneworff 1985; Ward et al. 1992; Urrutia et al. 1996; Barille et al. 1997). The latter is explained by the association between intact chlorophyll $a$ and, for many invertebrates, essential compounds such as polyunsaturated fatty acids (Boon and Duineveld 1996). In the discussion section, we relate our findings to specific features of the benthic community at the two stations.

\section{Materials and methods}

Study sites

From 17 to 22 November 1995 and from 7 to 10 May 1996, two locations in the southern North Sea were visited with the R.V. "Pelagia" (Fig. 1). Station B (depth $28 \mathrm{~m}$ ) is situated about 30 nautical miles off the Dutch coast $\left(53^{\circ} 00^{\prime} \mathrm{N}, 3^{\circ} 52^{\prime} \mathrm{E}\right)$ in the Broad Fourteens area. Station B is very close to one of the main stations (site A) where the North Sea sediment resuspension experiment (SERE) took place (see Jago and Jones 1998). Tidal current velocities at $0.5 \mathrm{~m}$ above the bottom vary between 10 and $45 \mathrm{~cm} \mathrm{~s}^{-1}$ (Boon and Duineveld 1996; Williams et al. 1998). The direction of the residual current is northwards. The sediment at stn B consists of medium sand $(247 \mu$ m median) with $<1 \%$ of silt and $<0.05 \%$ weight of organic $\mathrm{C}$. The macrobenthic biomass at stn $\mathrm{B}$ is relatively low $\left(\sim 5 \mathrm{~g} \mathrm{AFDW} \mathrm{m}^{-2}\right)$ and total annual sediment carbon demand is in the order of $30 \mathrm{~g} \mathrm{C} \mathrm{m}^{-2}$ (Boon and Duineveld 1998). Station F (depth $39 \mathrm{~m}$ ) is located about 60 nautical miles north of stn $\mathrm{B}$ on the slightly sloping transition zone between the Broad Fourteens and the Oyster Grounds $\left(53^{\circ} 42^{\prime} \mathrm{N}, 4^{\circ} 30^{\prime} \mathrm{E}\right)$. The area is characterized by a tidally induced front (Frisian front) between the permanently mixed water masses in the south and the summer-

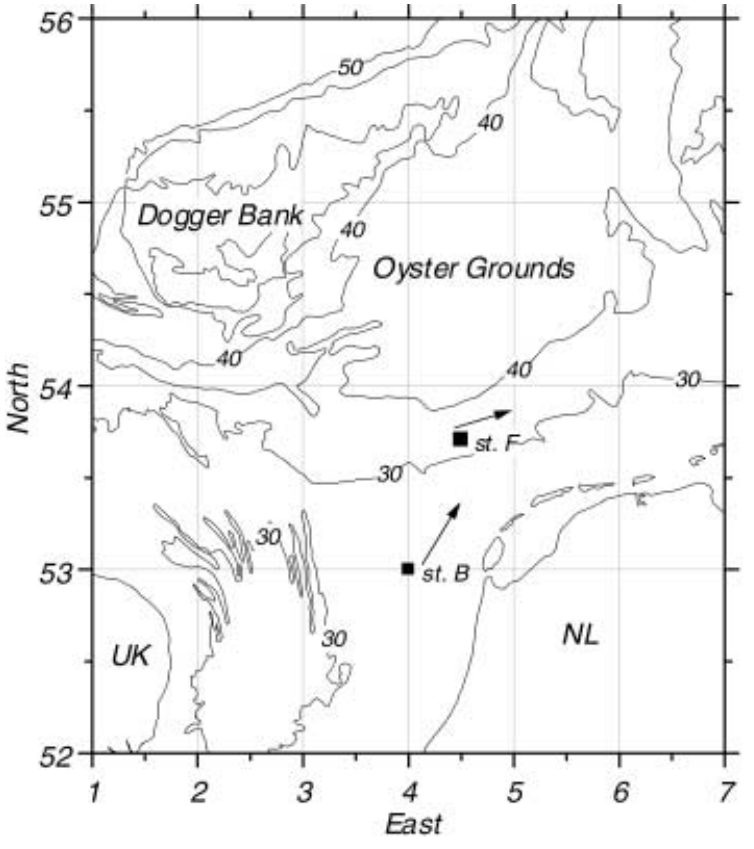

Fig. 1 Map of the southern North Sea showing station locations $(B$ and $F)$ and isobaths $(30 \mathrm{~m}$ and $40 \mathrm{~m})$. Arrows indicate the residual current directions

stratified water mass in the Oyster Ground. The sediment at stn $\mathrm{F}$ consists of very fine silty sand $(118 \mu \mathrm{m}$ median) with $\sim 30 \%$ silt and $0.5-1 \%$ weight of organic C. The sediment is inhabited by a relatively rich macrobenthic community (biomass $\sim 25 \mathrm{~g}$ AFDW $\mathrm{m}^{-2}$ ) and total annual carbon demand is more than three times the value at stn B (Boon and Duineveld 1998).

\section{Sampling and analytical procedures}

Near-bottom particles were captured with a sediment trap (Technicap PPS 4/3) and a sediment recorder (see below). The trap was suspended on a mooring line that was connected to a weight on the seabed and a drifter at the water surface. The distance between the trap entrance and the sea floor was $3.2 \mathrm{~m}$. This configuration allowed the trap to tilt, though this was not measured. The PPS $4 / 3$ trap is unbaffled and has a total height of $120 \mathrm{~cm}$ with a collecting area of $0.05 \mathrm{~m}^{2}$. The aspect ratio of the trap is $>4$, taking into account the full length of the trap. It holds a carousel with 12 sample cups $(250 \mathrm{ml}$ each). Prior to each deployment, the sample cups were filled with filtered (Whatman GF/F, $0.45 \mu \mathrm{m}$ ) local seawater, with no preserving agents added. The trap was deployed during the evening and the night from 1900 hours to 0700 hours (CET) and programmed to sample every hour, thus covering one tidal cycle.

The sediment recorder (Fig. 2) was designed to trap bed load transport, i.e., particles which move just above and over the sediment surface and which are potentially in reach of benthic organisms feeding at the sediment-water interface. The recorder basically consists of a carousel of $1 \mathrm{~m}$ diameter and $\sim 5 \mathrm{~cm}$ height, holding one dummy and 12 shallow cups $(10 \mathrm{~cm}$ diameter, $1 \mathrm{~cm}$ deep) which are covered by a smooth stainless steel plate with one opening of $10 \mathrm{~cm}$ diameter. The carousel neatly fits into in a low frame $(1.5 \times 1.5 \times 0.1 \mathrm{~m})$ with sloping edges $\left(30^{\circ}\right.$ angle $)$ to minimize disturbances of the boundary layer flow and the occurrence of eddies. A programmable electric motor inside the frame rotates the carousel underneath the cover plate so that one of the 12 cups is exposed in the opening in the cover plate (see arrow, Fig. 2). The inner side of the cups were covered with Velcro during the deployments in order to optimize entrainment of passing particles. The 
Fig. 2 A Photograph showing side (left) and top view (right) of the sediment recorder. Arrow points to the opening in the cover plate where the cup is exposed. B Diagram with top view of recorder showing the position of carousel and cups within the frame. The maximum dimensions of the frame are $1.5 \times 1.5 \times 0.1 \mathrm{~m}$
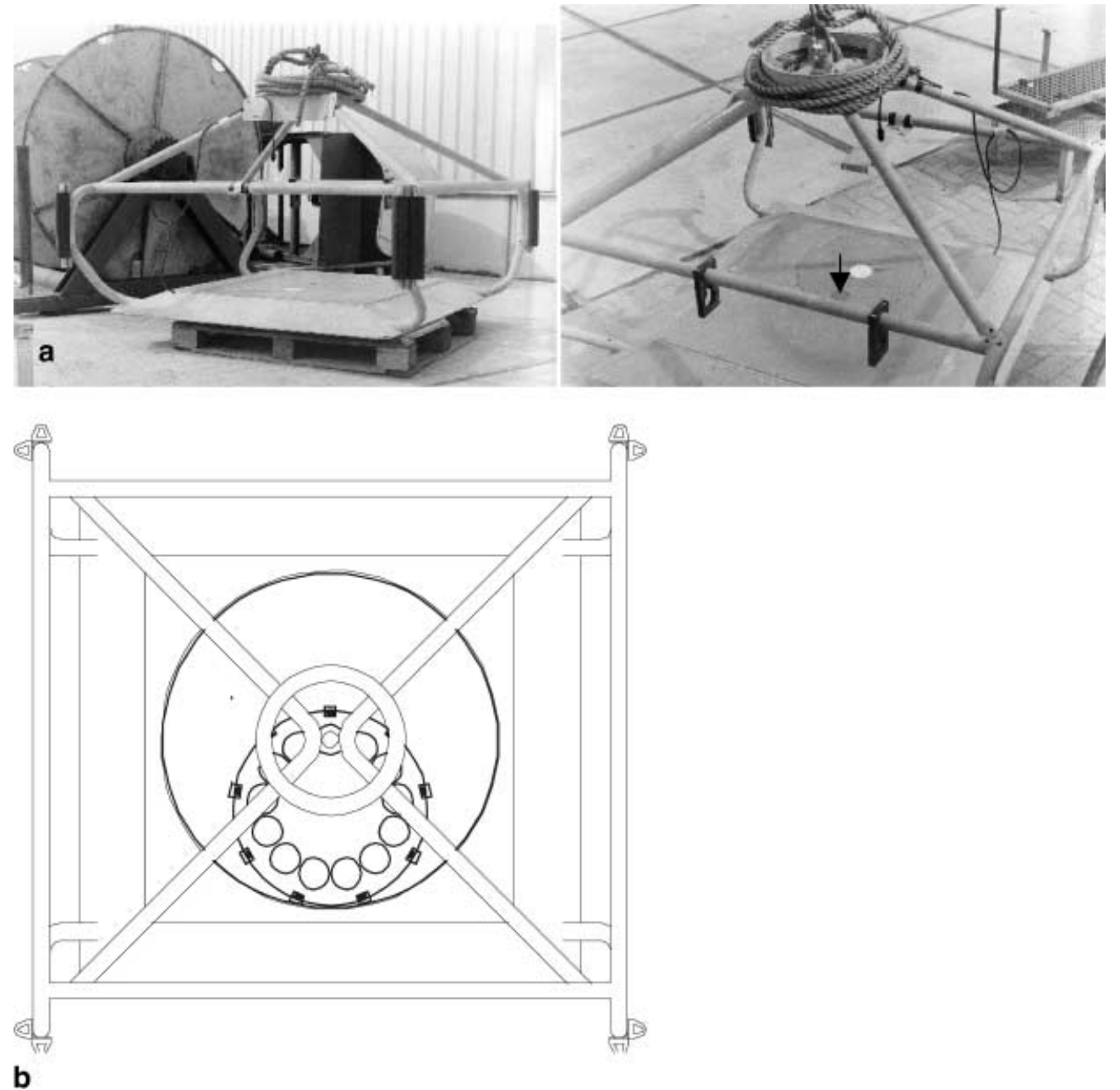

recorder was programmed to sample the same 12-h tidal cycle as the Technicap trap. An electromagnetic current meter (NIOZ) was attached to the recorder frame to monitor water-current velocity at approximately $0.5 \mathrm{~m}$ above bottom.

Station F was visited from 14 to 16 November 1995 (two consecutive nocturnal deployments) and from 6 to 7 May 1996 (one deployment). Station B was sampled from 20 to 22 November 1995 (two deployments) and from 8 to 9 May 1996 (one deployment). In November 1995, neap tide was on the 17th, and in May 1996 spring tide was around the 5th. For logistical reasons, no explicit choices could be made regarding deployment during certain spring or neap tides. During the nocturnal deployments of the devices, the direct surroundings ( $\sim 6$ nautical miles on radar) were observed for fishing boats. No active fishery was noted during these nights within this radius. Weather conditions before and during the deployments were relatively calm on both expeditions, with westerly winds (maximum $4 \mathrm{Bft}$ ). Hence, we assume that the external circumstances did not cause any resuspension of bottom material in and around the sampling sites during the deployments.

Immediately upon retrieval, samples were centrifuged (3,000 rpm, $3 \mathrm{~min})$ and residues were stored in glass vials at $-80^{\circ} \mathrm{C}$ until analysis in the laboratory. Dry weight was determined by first weighing the total sample and then taking a precisely weighed subsample. This subsample was gently rinsed three times with $2 \mathrm{ml}$ double-distilled water to remove salt, then dried at $60^{\circ} \mathrm{C}$ until constant weight, and then reweighed. Chlorophyll $a$ in the samples was separated by means of reversed-phase HPLC using the methods described by Boon and Duineveld (1998). Chlorophyll $a$ was identified by its spectrum and quantified using conversion factors derived from commercial standards (VKI, Copen- hagen). Statistical analyses were performed with untransformed data using software package Systat 5.4.

\section{Results}

\section{Near-bottom current velocity}

The near-bottom current velocity (hourly averages) at both stations are given in Figs. 3 and 4. At both stations the flood period lasted longer and was characterized by a higher current velocity than the ebb period. This is a typical feature of this part of the southern North Sea and is coherent with the residual water circulation, i.e., northward along the Dutch coast at stn B and north to east at stn F (Otto et al. 1990). The maximum near-bottom current velocity varied around $45 \mathrm{~cm} \mathrm{~s}^{-1}$ at stn B and between 20 and $25 \mathrm{~cm} \mathrm{~s}^{-1}$ at stn $\mathrm{F}$. The minimum current speed at stn B was somewhat higher as well, i.e., $10 \mathrm{vs}$ $5 \mathrm{~cm} \mathrm{~s}^{-1}$ at stn F. Also the average current velocity at stn $\mathrm{B}$ was higher than at stn $\mathrm{F}(t$-test, $P<0.05)$. Our current data from stn $B$ agree with the ranges found by Jago and Jones (1998). 

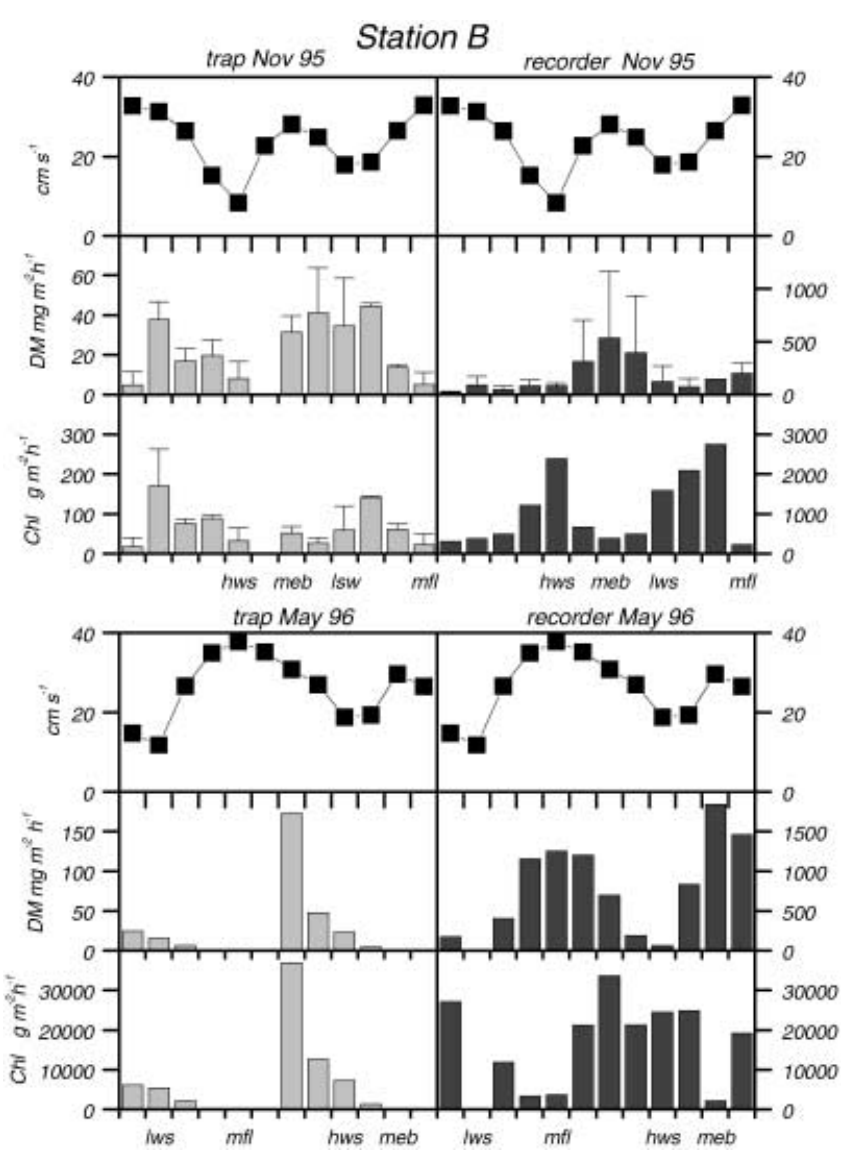

Fig. 3 Tidal variation in current velocity (20 min moving average in $\left.\mathrm{cm} \mathrm{s}^{-1}\right)$, dry matter flux $\left(D M\right.$ in $\left.\mathrm{g} \mathrm{m}^{-2} \mathrm{~h}^{-1}\right)$, and the chlorophyll $a$ flux ( $C h l$ in $\mu \mathrm{g} \mathrm{m}^{-2} \mathrm{~h}^{-1}$ ) during two deployments of the PPS4/3 sediment trap and the sediment recorder at station B. The error bars depict standard deviation. $h w s$ High water slack, lws low water slack, $m f l$ maximum flood, meb maximum ebb

Fluxes and composition of particulate matter

Figures 3 and 4 show the tidal variations in DM and $\mathrm{Chl}$ fluxes in the different instruments and seasons at the two stations. Samples from consecutive deployments which were taken during the same tidal period in November 1995 have been averaged. The standard deviation of these averages is shown by the error bars in Figs. 3 and 4. We also provide box plots which summarize the tideaveraged Chl:DM ratios in samples taken with the two devices in November and May at the two stations.

Trap at stn B

Both in November 1995 and May 1996 the DM fluxes in the PPS4/3 trap showed two peaks, namely after the maximum ebb and flood current (Fig. 3). However, the maximum DM flux was considerably higher in May 1996 than in November 1995, 170 and $45 \mathrm{mg} \mathrm{m}^{-2} \mathrm{~h}^{-1}$, respectively (Fig. 3). Figure 5 illustrates the strong and
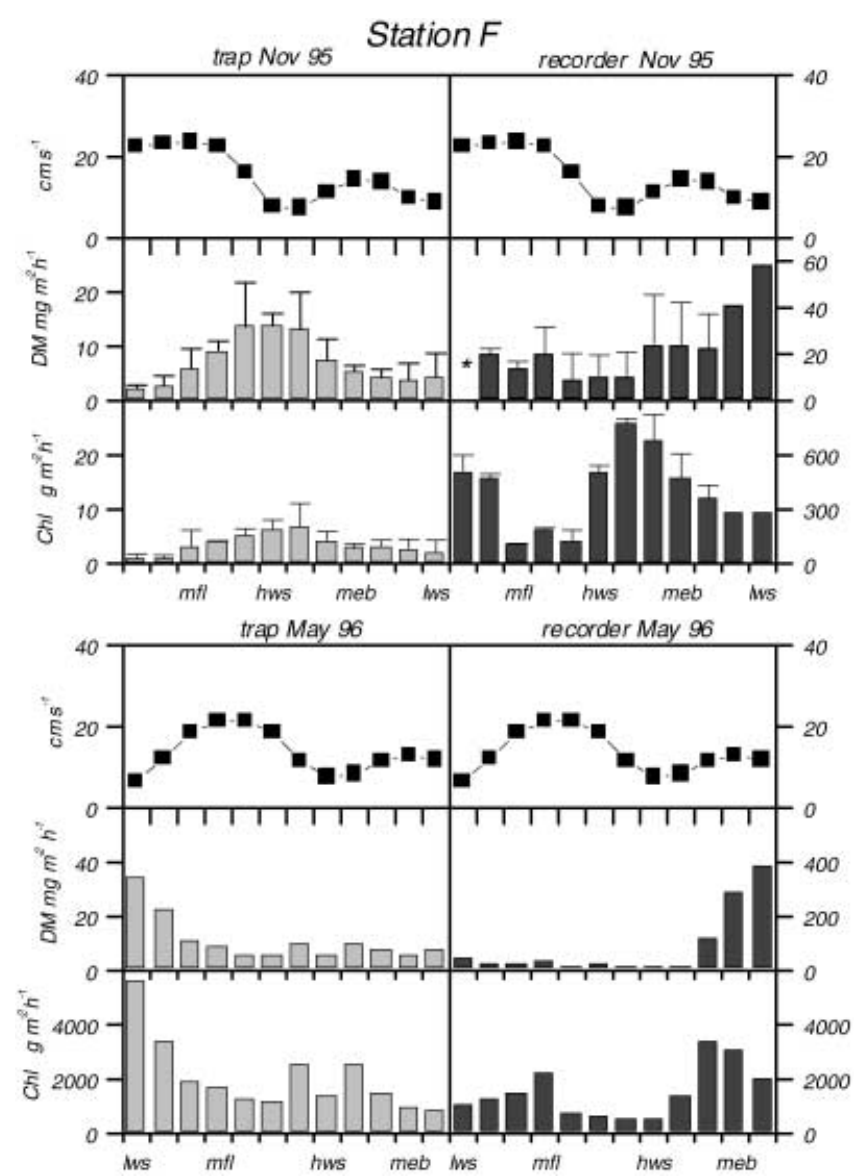

Fig. 4 Tidal variation in current velocity (20 min moving average in $\mathrm{cm} \mathrm{s}^{-1}$ ), dry matter flux ( $D M$ in $\left.\mathrm{g} \mathrm{m}^{-2} \mathrm{~h}^{-1}\right)$, and the chlorophyll $a$ flux ( $C h l$ in $\mu \mathrm{g} \mathrm{m}^{-2} \mathrm{~h}^{-1}$ ) during two deployments of the PPS4/3 sediment trap and the sediment recorder at stn F. The error bars depict standard deviations, asterisk denotes missing value. hws High water slack, lws low water slack, $m f l$ maximum flood, meb maximum ebb

significant association between fluxes of $\mathrm{Chl}$ and $\mathrm{DM}$ in trap deployments from November (Pearson's $r=0.64$, $P=0.001)$ and May $(r=0.99, P<0.001)$, indicating that Chl and DM particles have similar settling velocities or some physical-chemical bond. The magnitude of $\mathrm{Chl}$ fluxes clearly displays the effect of the spring bloom, i.e., the average flux in May $\left(6100 \mu \mathrm{g} \mathrm{m}^{-2} \mathrm{~h}^{-1}\right)$ was about two orders of magnitude higher than in November $(63 \mu \mathrm{g}$ $\left.\mathrm{m}^{-2} \mathrm{~h}^{-1}\right)$. This effect was also evident in the Chl:DM ratios, which varied between 0.6 and 7 (average 3.7) in November and around 300 in May.

Recorder at stn B

The range of DM fluxes in the two recorder deployments in November was 10-900 $\mathrm{mg} \mathrm{m}^{-2} \mathrm{~h}^{-1}$ (average 180) which is the same order of magnitude as the DM flux in May (Fig. 3). In both months, DM fluxes in the recorder were an order of magnitude higher than in the trap. In November 1995 one major peak in DM flux was ob- 
served during ebb while in May two peaks occurred; one coinciding with the ebb and the other with the flood currents (Fig. 3). The two series of Chl fluxes from November showed a close match with maximum values of up to $2,800 \mu \mathrm{g} \mathrm{m}^{-2} \mathrm{~h}^{-1}$ which is also an order of magnitude higher than maximum $\mathrm{Chl}$ fluxes in the trap $\left(235 \mu \mathrm{g} \mathrm{m}^{-2}\right.$ $\mathrm{h}^{-1}$ ). As a result of the spring bloom, the average $\mathrm{Chl}$ flux in May, $\sim 18,000 \mu \mathrm{g} \mathrm{m}^{-2} \mathrm{~h}^{-1}$, was much higher than in the preceding November. The maximum Chl flux in the recorder in May was similar to that in the trap. In contrast with the trap, DM and Chl fluxes in the recorder tended to be negatively correlated, though this was only (marginally) significant in the case of the May samples (Pearson's $r=-0.59, P=0.054$ ) (Fig. 5). The Chl:DM ratio in the recorder samples in November varied between 1 and 50 with an average of 19 , which was significantly higher (Wilcoxon, $P=0.0008$ ) than the average of 4 in the trap samples. In May a maximum Chl:DM ratio of 360 was reached in the recorder samples (average 69).

Trap at stn $\mathrm{F}$

Similarly to stn B, the two series of DM fluxes from November 1995 showed good agreement $(r=0.83, P<0.05)$ with a range of $1-20 \mathrm{mg} \mathrm{m}^{-2} \mathrm{~h}^{-1}$ (average 7) and one maximum around high water slack tide (Fig. 4). In May the following year we found a comparable range of 6-34 $\mathrm{mg} \mathrm{m}^{-2} \mathrm{~h}^{-1}$ (average 11) of DM fluxes but this time the highest values occurred at low water slack tide (lws, Fig. 4). Also at the Frisian front, trap fluxes of DM and Chl were significantly correlated in November (Pearson's $r=0.91, P<0.0001)$ and May $(r=0.97, P<0.0001)$ (Fig. 5a). Chl fluxes varied between 0 and $10 \mu \mathrm{g} \mathrm{m}^{-2} \mathrm{~h}^{-1}$ (average 3) in November, whereas in May this range increased to $850-5,600 \mu \mathrm{g} \mathrm{m}^{-2} \mathrm{~h}^{-1}$ (average 2,100) as a result of the spring bloom. The same increase was seen in the ratio Chl:DM, namely around 0.5 in November and on average 190 in May.

\section{Recorder at stn F}

The average DM fluxes in November ranged between 9 and $60 \mathrm{mg} \mathrm{m}^{-2} \mathrm{~h}^{-1}$ (average 20) and did not show a clear relationship with the tidal cycle (Fig. 4). In May we observed a strong increase in the DM fluxes in the recorder during the second half of ebb (Fig. 4) giving rise to a maximum of $390 \mathrm{mg} \mathrm{m}^{-2} \mathrm{~h}^{-1}$ (average 90 ). The Chl fluxes in November and May showed more or less comparable patterns with a peak during the ebb and a minor one during the first part of the flood (Fig. 4). However, the magnitude of the Chl fluxes was quite different, with an average of $90 \mu \mathrm{g} \mathrm{m}^{-2} \mathrm{~h}^{-1}$ (range 10-310) in November and $1,550 \mu \mathrm{g} \mathrm{m}^{-2} \mathrm{~h}^{-1}$ (range 500-3,500) in May. Unlike stn $\mathrm{B}$, fluxes of $\mathrm{Chl}$ and $\mathrm{DM}$ in the recorder were positively correlated both in November (Pearson's $r=0.41$, $P=0.014)$ and in May $(r=0.60, P=0.041)$ (Fig. 5b). Chl:DM ratios in the recorder samples from November
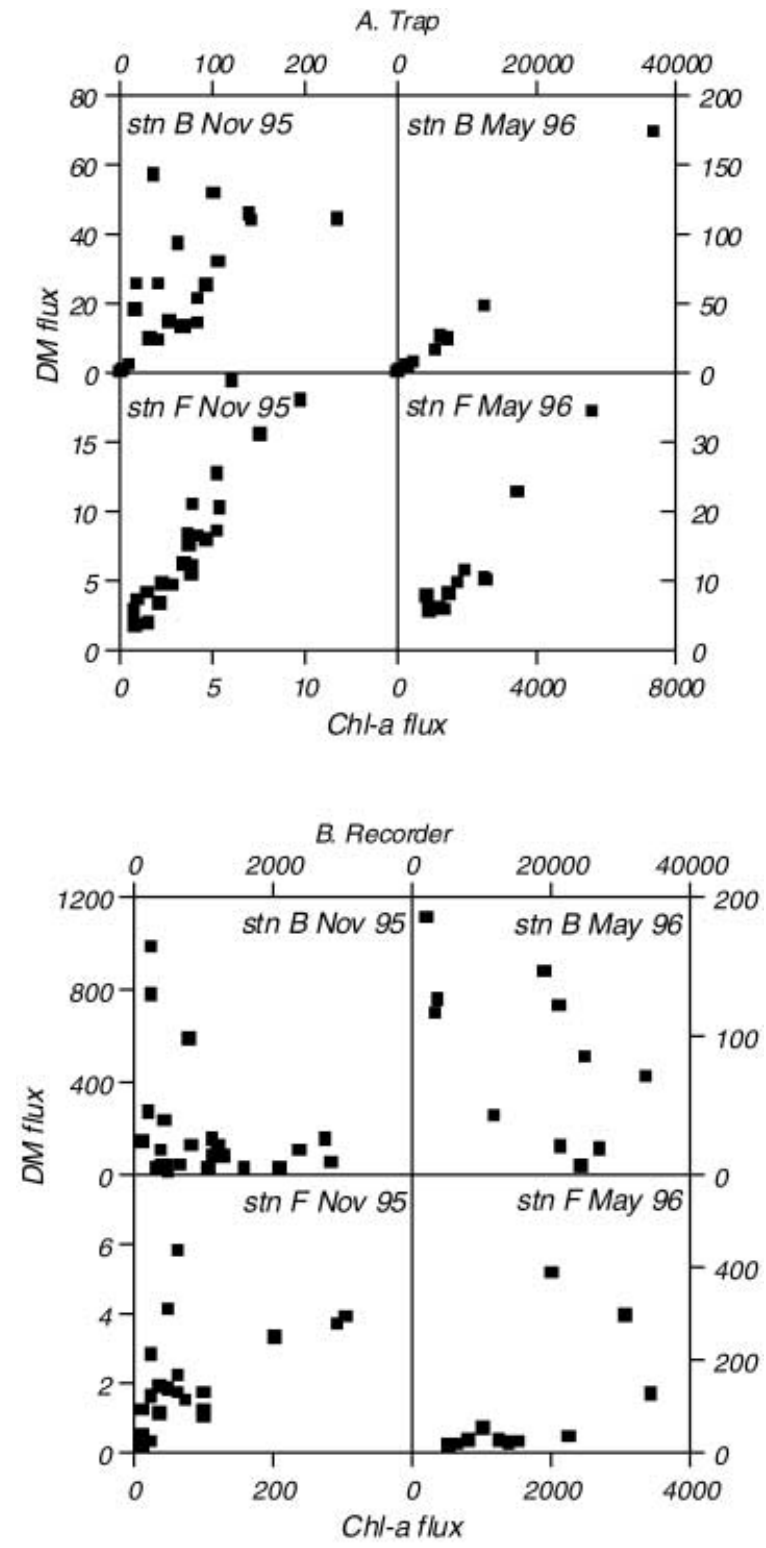

Fig. 5 Scatter plots showing the relation between the flux of dry matter $(D M)$ and chlorophyll $a(C h l)$ in the trap and recorder samples. See text for the correlations between the variables

were, similarly to stn $\mathrm{B}$, higher than in the trap samples, namely range $0.6-10$ (average 4.5), but in May they were markedly lower than in the trap samples, i.e., range 5-70 (average 39) (Fig. 6).

\section{Discussion}

In this study we compared the near-bottom fluxes of chlorophyll $a$ and dry matter measured with two types of devices. One of them was a new instrument designed to collect the bed load transport at approximately $10 \mathrm{~cm}$ above the seabed. In addition to the recorder we used a PPS4/3 sediment trap, which has been used in previous studies on particle transport and resuspension in the 
Fig. 6 Box and whisker plots of tidally averaged Chl:DM ratios in the samples taken with the recorder and the sediment trap. The line inside the box denotes the median value, the left and the right sides of the boxes are the 25 th and the 75 th percentiles, respectively, and the whiskers extend to the 5th and the 95th percentiles. Very high or low values are represented by an asterisk or an open circle, denoting values lying at a distance from the median more than $\sim 1.5$ and $\sim 3$ times the box size, respectively
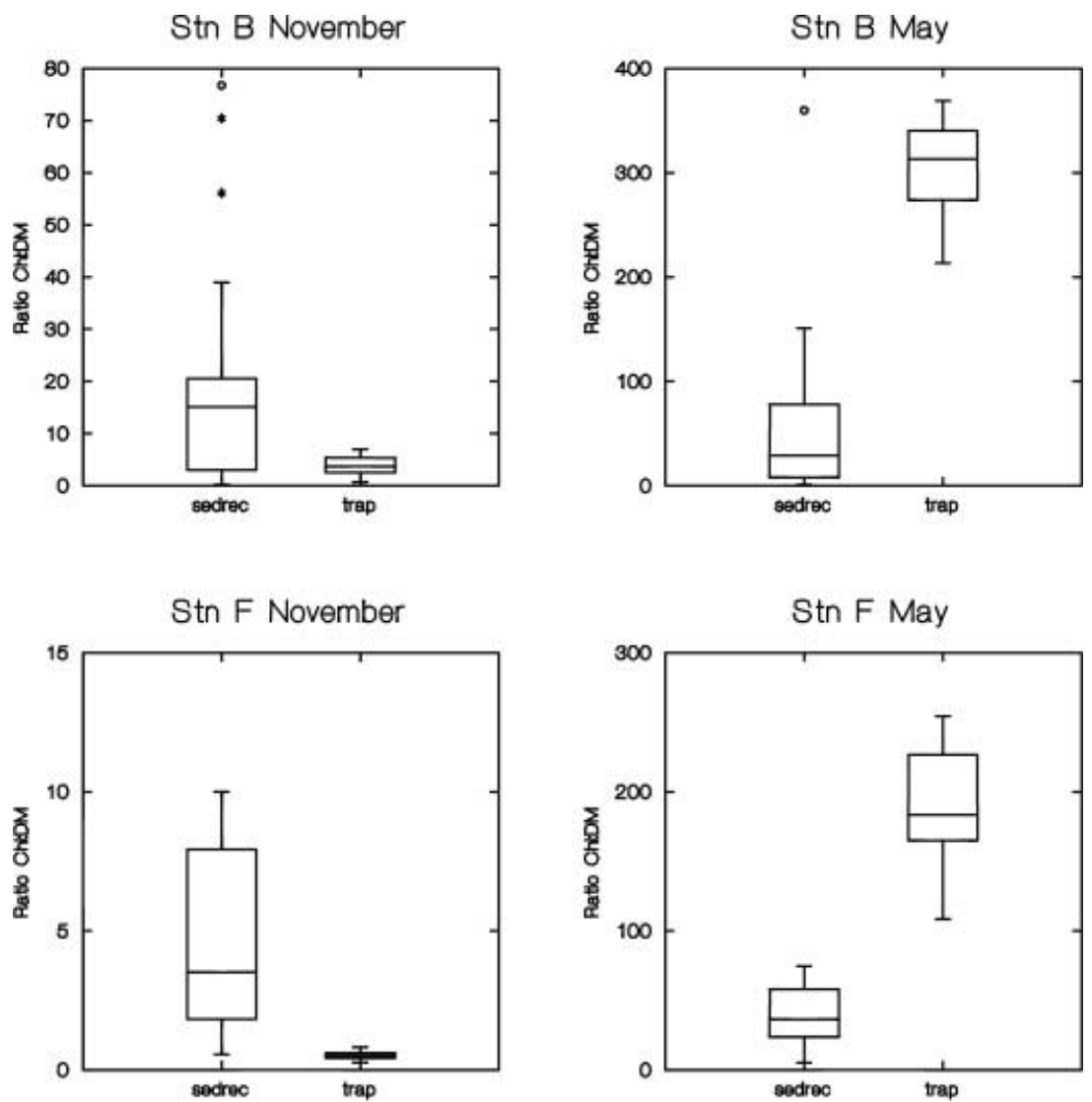

North Sea (e.g. van Duyl et al. 1997; van Raaphorst et al. 1998). Both the instruments that we used suffer from a lack of knowledge about their trapping efficiency. Various studies on the efficiency of sediment traps in turbulent waters have shown that trap shape, aspect ratio, tilt, and flow conditions are factors causing biased estimates (Gardner 1980; Gardner et al. 1983; Butman et al. 1986; Baker et al. 1988; Gust et al. 1994). Butman et al. (1986) and Baker et al. (1988) showed that a cylindrical trap with an aspect ratio of 4.4 and fixed in upright position starts to under-collect at currents greater than $12-20 \mathrm{~cm}$ $\mathrm{s}^{-1}$, due to the creation of an eddy inside the trap preventing particles from settling. Trap efficiency decreases further with decreasing fall velocity of the particles. According to Gardner (1985), tilted traps with an aspect ratio of 5.2, like our trap, are over-collectors compared with upright traps, especially for smaller, lighter particles. Since tilt increases with current speed, the efficiency also increases with current speed. Whilst the findings of the first two studies suggest that our trap at both stations partly underestimated the particle flux, and possibly more so at the silty stn $F$ where fine particles are more abundant, the tilting effect could have counterbalanced this lowered efficiency. As we did not measure tilt, the absolute magnitude of our trap fluxes should be considered with caution as they are possibly overestimated. van Raaphorst et al. (1998), who deployed a PPS 4/3 trap at a location 60 miles $\mathrm{N}$ of our stn $\mathrm{F}$, found considerably lower mass fluxes after they corrected for tilt measurements, although the tidal pattern did not change. However, a downward correction of our trap data would not substantially alter the outcome of our comparisons between particle quality and flux measured with the two instruments (see below).

The sediment recorder was designed using the principle that the sediment surface represents the most realistic sediment trap. Ideally this would have resulted in a shallow trap or collector tray which is completely flush with the sediment surface. This concept of hydrodynamically unbiased trays has been used by Snelgrove et al. (1998) for collecting settling larvae. The trays in the study of Snelgrove et al. were filled with sediment and placed by SCUBA divers. The trays in our device were filled with a Velcro lining instead of sediment in order to retain all particles that settled on the tray. In this way we hoped to get an idea of the potential food supply for an organism feeding at the interface. We mounted the collector trays in a frame which we designed to minimize the disturbance of the horizontal flow. Firstly, we made the recorder as flat as possible, within the constraints imposed by construction, and the surface as smooth as possible. The $10 \mathrm{~cm}$ height of the recorder is about twice the highest micro-topography in the central North Sea (see Rowden et al. 1998). Secondly, we reduced abrupt disturbance of the flow field by making sloping edges on the frame (see Snelgrove et al. 1995), and thirdly we maximized the distance between the central opening and the edge $(50 \mathrm{~cm})$ to allow the flow to resume its original 
condition. Acknowledging the lack of objective data on the performance of our devices we still report the results obtained so far with the recorder because they showed consistent and marked differences with those of the trap both with regard to the magnitude and quality of the fluxes and to their variation in the tide.

The deployment of the instruments yielded some consistent device-specific patterns. A common and conspicuous feature of all trap deployments is the strong correlation between Chl and DM (Fig. 5a). In the case of the silty stn F, an obvious explanation is the similarity in settling velocities of the abundant fine sediment particles and chlorophyll-containing particles. Because we expect the hydrodynamic sorting of sediment and organic detritus to be stronger at stn B, the correlation of Chl and DM more likely indicates one type of particle or aggregate which accounts for both DM and Chl. The consistently higher Chl:DM ratio in trap samples from stn B (Fig. 6) supports a different composition of trapped material at the two stations, i.e., a mixture of sedimentary and organic particles at stn $\mathrm{F}$ and mainly organic particles at stn B.

The trap at stn B caught most particles during the decrease of the ebb and flood currents. This is especially evident in May 1996, when a sharp peak in Chl and DM flux was found during the second half of the flood period (Fig. 3). Most likely, the flux peaks in the trap at stn B in May 1996 and possibly also the peak in November 1995 represents the re-settling of phytodetritus which had earlier been resuspended by tidal currents. Such alternate settling and re-suspension of a fluffy detritus layer at stn $\mathrm{B}$ during the spring bloom has been reported earlier by Jenness and Duineveld (1984) and Jago and Jones (1998). The trap data from the silty station stn F, especially those from May, are in line with observations by van Raaphorst et al. (1998) on a nearby location with a similar sediment type and maximum current velocity. They also found that the main particle flux in their trap took place during and shortly after low water slack tide, while minimum fluxes were observed during ebb current (Fig. 4). The shift in maximum flux that we observed between the trap samples from stn B and those from stn F indicates that there is a difference in particle density with the lowest settling velocities, i.e., lower densities at stn F.

Recorder samples from both stations clearly showed a different picture than the trap samples. In the recorder at stn B, the highest DM fluxes occurred during high tides, whereas the highest $\mathrm{Chl}$ fluxes were measured mainly during slack tide (Fig. 3). The negative correlation between Chl and DM in the recorder samples (Fig. 5b) suggests that different kinds of particles were caught at stn B, i.e. the DM flux was possibly composed of "heavy" sediment particles which predominantly move as bed load during high currents [see current ripples in Jenness and Duineveld (1984)], and lighter phytodetritus particles re-settling during decreasing flood currents (see above). This is especially clear in May (Fig. 3) when the highest Chl fluxes coincide with low fluxes of DM, and hence the Chl:DM ratio attains maximum values. At stn $\mathrm{F}$, with its fine sediment and reduced maximum current velocities, the distinction between sediment and phytodetritus is less straightforward than at stn B, i.e., peaks in $\mathrm{DM}$ and $\mathrm{Chl}$ fluxes tended to coincide in the recorder as illustrated by their positive correlation in Fig. 5b. Another contrast with stn B is that in May, when there was plenty of chlorophyll present, Chl fluxes in the recorder peaked during increase of ebb and (less so) during flood currents (Fig. 4). We interpret this pattern as evidence of the movement of part of the phytodetritus as bed load during the weaker ebb currents. Apart from the relatively weak currents unable to resuspend all phytodetritus, particle aggregation could also play a role. The rate of flocculation is proportional to particle cohesiveness while the organic content of particles increases this cohesiveness (Lick et al. 1992; Chen 1995). Such a process is more likely to occur between organic-carbon-rich silty particles and detritus (stn F) than between sandy, relatively organic-carbon-poor particles and detritus ( $\operatorname{stn} \mathrm{B}$ ).

There were two conspicuous results of this study which we had not anticipated. One concerns the relatively high values of the Chl flux (Figs. 3 and 4) and of the Chl:DM ratio (Fig. 6) in the recorder samples from November compared with the trap at both stations. Especially at the turbulent, sandy stn B, we had expected that hydrodynamic sorting of detritus and relatively heavy bed load would be strongest, resulting in a higher proportion of lighter, organic-rich particles in the trap than in the recorder (Mayer et al. 1993). Our result could be explained by assuming that the phytodetritus particles in November were older than those in May and had thus had longer time to be converted into larger heavy aggregates which better resist resuspension. An analogous phenomenon has been described in deeper waters where the concentration of chlorophyll increases close to the sea floor due to repackaging and formation of heavy aggregates which are not easily resuspended (Thomsen and Graf 1994). A second unexpected result of the recorder deployments is that in both seasons stn B yielded higher Chl fluxes and Chl:DM ratios than stn F. Earlier studies had all found that sediment cores from stn $\mathrm{F}$ contain higher concentrations of chlorophyll $a$ than those from stn B (Cramer 1990; Boon and Duineveld 1998). The relatively high sediment inventory of chlorophyll at stn $\mathrm{F}$ is consistent with the elevated chlorophyll levels measured in the water column at this station (Cramer 1990; Boon et al. 1998). We therefore assumed that we would find the highest near-bed $\mathrm{Chl}$ fluxes at stn $\mathrm{F}$ and most likely a higher quality of particles (Chl:DM ratios) as well. Rather than speculating about the causes (e.g., different water column levels of $\mathrm{Chl}$ or flocculation intensity), we wish at this point only to stress that there is a clear discrepancy between our recorder results and what is known of sediment properties and benthic biomass at the two stations.

The high near-bottom Chl flux at stn B sharply contrasts with the relatively low sediment chlorophyll inventory, biomass and sediment respiration rate (Osinga 
1996; Boon et al. 1998; Dauwe et al. 1998). Dauwe et al. (1998) argued that most of the organic fluff at stn B is kept in suspension, and therefore the total available pool is too low to support a large biomass. They further attributed the low chlorophyll inventory at stn B to the comparatively high particle quality, as we also found, which leads to rapid degradation in the surface layer. Our recorder data show that, at least during the periods of our observations, the potentially available amount of phytodetritus is quite high compared with the more quiescent stn F (Figs. 3 and 4). Therefore it seems that for some reason the exploitation of this source by macrobenthos and likely also by bacteria (i.e., low sediment respiration rate) is hampered. Though the relatively high current velocities at stn B positively affect the encounter rate between particles and feeding appendages of organisms, they also put a strain on the feeding efficiency of interface feeders and hence on biodeposition. In a study by Miller et al. (1992), current velocities above $20 \mathrm{~cm} \mathrm{~s}^{-1}$ severely hampered feeding activity of many suspension and surface deposit feeders, due to increased drag forces on the feeding appendages. Important in this context is our finding that the best quality near-bottom particles are found around slack tides (see Jenness and Duineveld 1985), in other words when current velocities are low and feeding is facilitated. Possibly the much shorter time window for feeding at stn $\mathrm{B}$ in comparison to stn $\mathrm{F}$ is not compensated for by the higher quality of the particles.

Interface feeders such as the bivalves Chamelea striatula and Donax vittatus which live in turbulent sand habitats in the North Sea are quite rare at stn B. The only interface feeder which attains an appreciable population at stn B is the common heart-urchin Echinocardium cordatum, a species known as a subsurface deposit feeder but which is also capable of interface feeding. Duineveld and Jenness (1984) showed that E. cordatum grows faster and attains larger test lengths at stn B than at stn F. Next to its capability to alternate its feeding mode, a second explanation for the success of E. cordatum and the apparent failure of, for instance, bivalves could be the reproductive strategy of the first species. Each year in May and June there is an outburst of E. cordatum larvae, which dominate the meroplankton in the southern North Sea. Larvae of bivalves occur in lower numbers and are much more dispersed over the year (Bosselmann 1989). Given the frequency of disturbance of the sediment by beam-trawl fishery and erosion due to tides and storms, the pulse strategy of E. cordatum could in the long run well be more profitable than that of bivalves. Dauwe et al. (1998) also hypothesize that environmental stress at stn B is not only keeping food in suspension but may also inhibit larval settlement or erosion of settled stages of suspension feeders.

Our study of the near-bottom food supply with a newly developed recorder yielded evidence that the quantity and quality of potentially available food for interface feeders at stn B surpasses that at stn F. The low macrobenthos biomass at stn $\mathrm{B}$, however, points to a low rate of exploitation. These observations lead to the question of what regulates the benthic productivity at stn B, which is located in an important area for demersal fishing in the southern North Sea. This lack of knowledge about basic principles in one of the most exploited areas of the southern North Sea emphasizes the need for further work on the relation between food supply and its utilization by invertebrates, involving studies on the processes which govern the supply of food particles and of recruits of benthic invertebrates.

Acknowledgements The crew of the RV "Pelagia" is acknowledged for their assistance on board the vessel. We are grateful for the effort that NIOZ technicians put into the construction of the sediment recorder. We thank Magda Bergman for letting us join the cruise in May 1996. Dr Wim van Raaphorst and Dr Laurenz Thomsen gave constructive comments on earlier versions of this paper. This study was made possible by a grant from the Dutch Organization for Scientific Research (NWO).

\section{References}

Abelson A, Miloh T, Loya Y (1993) Flow patterns induced by substrata and body morphologies of benthic organisms and their role in determining the availability of food particles. Limnol Oceanogr 38:1116-1124

Baker ET, Milburn HB, Tennant DA (1988) Field assessment of sediment trap efficiency under varying flow conditions. J Mar Res 46:673-592

Barille L, Prou J, Heral M, Razet D (1997) Effects of high natural seston concentrations on the feeding selection and absorption of the oyster Crassostrea gigas. J Exp Mar Biol Ecol 212:149-172

Bayne BL, Iglesias JIP, Hawkins AJS, Navarro E, Heral M, Deslous-Paoli JM (1993) Feeding behaviour of the mussel Mytilus edulis: responses to variations in quantity and organic content of the seston. J Mar Biol Assoc UK 73:813-829

Boon AR, Duineveld GCA (1996) Phytopigments and fatty acids as molecular markers of near-bottom particulate organic matter in the North Sea. J Sea Res 35:279-291

Boon AR, Duineveld GCA (1998) Chlorophyll-a as a marker for bioturbation and carbon flux in southern and North Sea sediments. Mar Ecol Prog Ser 162:33-43

Boon AR, Duineveld GCA, Berghuis EM, Weele JA van der (1998) Relationships between benthic activity and the annual phytopigment cycle in near-bottom water and sediments in the southern North Sea. Estuar Coast Shelf Sci 46:1-13

Bosselmann A (1989) Larval plankton and recruitment of macrofauna in a subtidal area in the German Bight. In: Ryland JS, Tyler PA (eds) Reproduction genetics and distribution of marine organisms: proceedings of the 23rd European marine biology symposium. Olsen and Olsen, Denmark, pp 43-53

Butman CA, Grant WD, Stolzenbach KD (1986) Predictions of sediment trap biases in turbulent flows: a theoretical analysis based on observations from the literature. J Mar Res 44:601644

Chen S (1995) Floc size and flocculation processes of suspended particulate matter in the North Sea. PhD thesis, University of Utrecht

Christensen H, Kanneworff E (1985) Sedimenting phytoplankton as major food source for suspension and deposit feeders in the Øresund. Ophelia 24:223-244

Cramer A (1990) Seasonal variation in benthic metabolic activity in a frontal system in the North Sea. In: Barnes M, Gibson RN (eds) Trophic relationships in the marine environment: proceedings of the 24th European marine biology symposium. Aberdeen University Press, Aberdeen, pp 54-76

Creutzberg F (1986) Distribution patterns of two bivalve species (Nucula turgida, Tellina fabula) along a frontal system in the southern North Sea. Neth J Sea Res 20:305-311 
Creutzberg F, Wapenaar P, Duineveld GCA, Lopez Lopez N (1984) Distribution and density of the benthic fauna in the southern North Sea in relation to bottom characteristics and hydrographical conditions. Rapp P-V Reun Cons Int Explor Mer 183:101-110

Dauwe B, Herman PMJ, Heip CHR (1998) Community structure and bioturbation potential of macrofauna at four North Sea stations with contrasting food supply. Mar Ecol Prog Ser 173:67-83

Davoult D, Gounin F (1995) Suspension-feeding activity of a dense Ophiotrix fragilis (Abildgaard) population at the water-sediment interface: time coupling of food availability and feeding behaviour of the species. Estuar Coast Shelf Sci 41:567-577

Duineveld GCA, Jenness MI (1984) Differences in growth rates of the sea urchin Echinocardium cordatum as estimated by the parameter $\omega$ of the von Bertalanffy equation applied to skeletal rings. Mar Ecol Prog Ser 19:65-72

Duyl FC van, Duineveld GCA, Kop AJ (1997) Short-term variability in pelagic-benthic exchange of phytopigments and their relations to benthic bacterial variables in the North Sea. Aquat Microb Ecol 13:47-61

Eckman JE (1996) Closing the larval loop: linking larval ecology to the population dynamics of marine benthic invertebrates. J Exp Mar Biol Ecol 200:207-237

Fegley SR, MacDonald BA, Jacobsen TR (1992) Short-term variation in the quantity and quality of seston available to benthic suspension feeders. Estuar Coast Shelf Sci 34:393-412

Gardner WD (1980) Field assessment of sediment traps. J Mar Res 38:41-52

Gardner WD (1985) The effect of tilt on sediment trap efficiency. Deep-Sea Res 32:349-361

Gardner WD, Richardson MJ, Hinga KR, Biscaye PE (1983) Resuspension measured with sediment traps in a high-energy environment. Earth Planet Sci Lett 66:262-278

Gust G, Michaels AF, Johnson R, Deuser WG, Bowles W (1994) Mooring line motions and sediment trap hydromechanics: in situ intercomparison of three common deployment designs. Deep-Sea Res 41:831-857

Jago CF, Jones SE (1998) Observation and modelling of the dynamics of benthic fluff resuspended from a sandy bed in the southern North Sea. Cont Shelf Res 18:1255-1282

Jago CF, Bale AJ, Green MO, Howarth MJ, Jones SE, McCave IN, Millward GE, Morris AW, Rowden AA, Williams JJ (1993) Resuspension processes and seston dynamics, southern North Sea. Philos Trans R Soc Lond A 343:475-491

Jenness MI, Duineveld GCA (1985) Effects of tidal currents on chlorophyll $a$ content of sandy sediments in the southern North Sea. Mar Ecol Prog Ser 21:283-287

Lick W, Lick J, Ziegler CK (1992) Flocculation and its effect on the vertical transport of fine-grained sediments. Hydrobiologia 235/236:1-16

Loo L-O, Jonsson PR, Sköld M, Karlsson O (1996) Passive suspension feeding in Amphiura filiformis (Echinodermata Ophiuroidea): feeding behaviour in flume flow and potential feeding rate of field populations. Mar Ecol Prog Ser 139:143-155
Mayer LM, Jumars PA, Taghon GL, Macko SA, Trumbore S (1993) Low-density particles as potential nitrogenous foods for benthos. J Mar Res 51:373-389

Miller DC, Bock MJ, Turner EJ (1992) Deposit and suspension feeding in oscillatory flows and sediment fluxes. J Mar Res 50:489-520

Mills EL (1975) Benthic organisms and the structure of marine ecosystems. J Fish Res Board Can 32:1657-1663

Osinga R (1996) Sedimentation and degradation of organic matter produced by marine phytoplankton. $\mathrm{PhD}$ thesis, State University Groningen, The Netherlands

Otto L, Zimmerman JTF, Furnes GK, Mork M, Sætre R, Becker G (1990) Review of the physical oceanography of the North Sea. Neth J Sea Res 26:161-238

Raaphorst W van, Malschaert JFP, Haren JJM van (1998) Tidal resuspension of particulate matter in the Oyster Grounds, North Sea. J Mar Res 56:257-291

Rosenberg R (1995) Benthic marine fauna structured by hydrodynamic processes and food availability. Neth $\mathrm{J}$ Sea Res 34:303-317

Rowden AA, Jones MB, Morris AW (1998) The role of Callianassa subterranea (Montagu) (Thalassinidae) in sediment resuspension in the North Sea. Cont Shelf Res 18:1365-1380

Snelgrove PVR, Butman CA (1994) Animal-sediment relationships revisited: cause versus effect. Oceanogr Mar Biol Annu Rev 32:111-177

Snelgrove PVR, Butman CA, Grassle JF (1995) Potential flow artefacts associated with benthic experimental gear: deep-sea mudbox examples. J Mar Res 53:821-845

Snelgrove PVR, Grassle JP, Grassle JF, Petrecca RF, Ma H (1998) In-situ habitat selection by settling larvae of marine soft-sediment invertebrates. Limnol Oceanogr 44:1341-1347

Sun M-Y, Aller RC, Lee C (1994) Spatial and temporal distributions of sedimentary chloropigments as indicators of benthic processes in Long Island Sound. J Mar Res 52:149-176

Thomsen L, Graf G (1994) Boundary layer characteristics of the continental margin of the western Barents Sea. Oceanol Acta 17:597-607

Urrutia MB, Iglesias JIP, Navarro E, Prou J (1996) Feeding and absorption in Cerastoderma edule under environmental conditions in the Bay of Marennes-Oleron (Western France). J Mar Biol Assoc UK 76:431-450

Wakeham SG, Lee C, Hedges JI, Hernes PJ, Peterson Ml (1997) Molecular indicators of diagenetic status in marine organic matter. Geochim Cosmochim Acta 61:5363-5368

Ward JE, Cassell HK, MacDonald BA (1992) Chemoreception in the sea scallop Placopecten magellanicus (Gmelin). I. Stimulatory effects of phytoplankton metabolites on clearance and ingestion rates. J Exp Mar Biol Ecol 163:235-250

Williams JJ, Humphery JD, Hardcastle PJ, Wilson DJ (1998) Field observations of hydrodyamic conditions and suspended particulate matter in the southern North Sea. Cont Shelf Res $18: 1215-1233$ 